Miodrag Vujanović, dipl. inž.

Pavao Begović, potpukovnik, dipl. inž.

dr Miljko Erić,

pukovnik, dipl. inž.

Vojnotehnički institut,

Beograd

Stojan Ninić,

potpukovnik, dipl. inž.

VP 1120, Beograd

\section{ZAŠTITA OBJEKATA I NADGLEDANJE PROSTORA PASIVNIM MULTISENZORSKIM ELEKTRONSKIM SISTEMIMA}

UDC: $621.397: 621.396 .664]: 725.004 .4$

Rezime:

Analizom savremenih borbenih dejstava uočava se više značajnih karakteristika koje predstavljaju opšte, zajedničko obeležje svih savremenih operacija. Dominantna je, svakako, karakteristika sveobuhvatnosti borbenih dejstava i po prostoru i po vremenu. To znači da za uspešno vodenje savremenih operacija treba, u svakom trenutku, raspolagati pouzdanim podacima o svim aktivnostima u prostoru (kretanje ljudstva, tehnike, njihove pozicije, meteorološki podaci, itd.). Ove podatke generišu, na osnovu odgovarajućih detektovanih parametara, savremeni elektronski multisenzorski sistemi disperzirani u prostoru. U radu su izložene osnovne karakteristike sistema za zaštitu objekata i prostora koji se koriste u savremenim armijama. Dat je prikaz aktivnosti Vojnotehničkog instituta u realizaciji sistema PRESEK, koji je namenjen za perimetarsku zaštitu objekata i prostora. Izložena je i koncepcija novog multisenzorskog sistema za zaštitu objekata i prostora, čiji je osnovni uređaj univerzalna akviziciona platforma, koja treba da prihvati različite vrste pasivnih senzora i omogući pasivno ili aktivno nadgledanje prostora prenosom TV slike.

Ključne reči: zaštita objekata i nadgledanje prostora, pasivni multisenzorski elektronski sistemi, PRESEK, akviziciona platforma, pasivni senzori, TV slika.

\title{
SECURITY PROTECTION AND AREA MONITORING BY PASSIVE MULTI-SENSOR SYSTEMS
}

Summary:

Analyzing modern low level intensity wars and crises, we find some important characteristics that are similar or same for each one. The most dominant are: combat actions in whole space without time limitations which means that, if you want to be successful in predicting enemy's activities, you continually need to know about enemy's activities in battlefield (people moving, moving of armor vehicles, artilleries and their positions, meteorological data, etc.). That kind of data is successfully obtained by passive multi-sensor systems dispersed in space of expected battle. We will introduce the philosophy of modern systems that are in use in NATO armies, activities of Military Technical Institute in realization of such a system named PRESEK, and developing of new passive multisensor system with CCTV.

Key words: security protection and area monitoring, passive multi-sensor acquisition system, acquisition platform, passive sensors, CCTV (close crcuit television).

\section{Uvod}

Uspešno vođenje ratnih operacija, antiterorističkih dejstava i drugih vrsta intervencija borbenih jedinica zavisi od raspoloživosti i pouzdanosti podataka o svim aktivnostima u prostoru (kretanje ljudstva, tehnike, njihove trenutne pozicije, meteo podaci, itd.). Ove podatke generišu, na osnovu odgovarajućih detekto- 
vanih parametara, savremeni elektronski multisenzorski sistemi disperzirani u prostoru, odnosno sistemi tehničke zaštite objekata i prostora (u daljem tekstu sistem TZOP) u širem smislu.

Osnovna namena sistema TZOP je detekcija (otkrivanje) uzroka narušavanja bezbednosti štićenog objekta i nadgledanog prostora, identifikacija uzročnika (čovek, vozilo i sl.) i određivanje pozicije uzročnika.

Sistem TZOP, u sklopu bezbednosnog obezbeđenja borbenih dejstava (realnih ili vežbovnih), sistemu komandovanja daje podatke koji treba da povećaju efikasnost odlučivanja o preventivnom, ofanzivnom ili odbrambenom dejstvu jedinica. U sklopu antiterorističkih dejstava i dejstava za sprečavanje krimogenih aktivnosti (krijumčarenje narkotika, naoružanja i belog roblja, ilegalna migracija i sl.) sistem TZOP obezbeđuje podatke o tipu uzročnika, a primenom biometrijskih metoda identifikacije i podatke o identitetu osobe koja narušava bezbednost štićenog objekta (npr. granični prelaz, aerodromski ulaz i sl.) i nadgledanog prostora (granični pojas i sl.).

Sistem TZOP može biti stacionaran ili prenosni sa stanovišta vrste, namene, nivoa zaštite i značaja objekta ili prostora koji se štiti.

Stacionarni sistemi TZOP namenjeni su za neprekidni nadzor i sprečavanje neovlašćenog ulaska u štićeni objekat ili prostor, pri čemu se za povezivanje uređaja u sistem koristi fiksna kablovska instalacija. Ovi sistemi omogućavaju stalno praćenje bezbednosnog stanja na objektu zaštite, a u slučaju pokušaja i ulaska nepozvanih lica omogućavaju pravovremenu intervenciju fizičkog obezbeđenja (straža, patrola, interventna jedinica) na lokaciji upada. Ako štićeni objekat nema posadu, obezbeđena je daljinska dojava alarma po PTT liniji najbližoj interventnoj jedinici. Evidentno je da su stacionarni sistemi namenjeni za zaštitu objekata i prostora $\mathrm{u}$ miru, dok $\mathrm{u}$ toku izvođenja borbenih dejstava bilo koje vrste kablovske komunikacione instalacije postaju prva meta napadača, pa je sistem upotrebljiv samo do trenutka uništenja ove instalacije.

Prenosni sistemi TZOP namenjeni su za zaštitu delova državne granice (uključujući i administrativnu liniju prema KiM u KZB), komandnih mesta u rejonu razmeštaja, vatrenih položaja artiljerijsko-raketnih jedinica, poljskih skladišta municije, MES i pogonskog goriva, ratnih bolnica i drugih osetljivih elemenata borbenog rasporeda jedinica. Ovi sistemi se zasnivaju na radio-vezi kao osnovnom mediju za prenos senzorskih signala ili podataka do centralnog uređaja, a kod prenosnih sistema novih generacija se koristi i satelitska komunikacija. Na ovaj način omogućeno je postavljanje senzora na većim rastojanjima od centralnog uređaja, koji je smešten unutar objekta ili prostora koji se štiti, kao i na prostorima koji su van vidnog polja osmatrača (iza brda, šume, nasipa...).

\section{Trendovi u oblasti sistema TZOP}

\section{Stacionarni sistemi TZOP}

Prema raspoloživim podacima o iskustvima koje imaju strane armije u oblasti primene sistema TZOP, primena bezbednosnih mera se planira u skladu sa potrebama i zahtevima koji proističu iz 
značaja objekta ili prostora koji se štite. $\mathrm{Na}$ pristup realizaciji stacionarnih sistema TZOP utiču tip objekta ili materije koji se štite, priroda okoline objekta ili kompleksa, prethodno bezbednosno iskustvo korisnika i procena ugroženosti. Ova zapažanja formiraju osnovu za inicijalnu procenu korisnika. Međutim, retko su dovoljna za razvoj delotvorne konfiguracije sistema TZOP. Priroda i tempo aktivnosti u okolini lokacije ili objekta, fizička konfiguracija lokacije ili objekta, prirodno i urbano okruženje, klimatska kolebanja i varijacije, ali i primena novih ili proverenih tehnologija, faktori su koje treba razmotriti prilikom projektovanja sistema TZOP.

$\mathrm{Na}$ realizaciju stacionarnih sistema TZOP utiču i eskalacija terorističkih dejstava u poslednjih petnaest godina (drastični primeri su Njujork 2001. i Madrid 2004. godine), ali i brojni objekti i kompleksi van granica domicilnih država (vojne baze, baze mirovnih misija i kompleksi humanitarnih organizacija, diplomatska predstavništva i kompleksi) za čiju su bezbednost te države odgovorne (SAD, Rusija, države EU i dr.), bez obzira na eventualni privremeni karakter navedenih objekata. Ovaj izazov zahteva dinamičan i kreativan pristup, posebno u domenima perimetarske zaštite i kontrole pristupa osoba. Tipični primeri lokacija (slika 1) na kojima se realizuju stacionarni sistemi TZOP su logistička skladišta, objekti za istovar i održavanje brodova i aviona, objekti za smeštaj ljudstva, komunikacioni centri i komandna mesta.

Iako izazovi vezani za kontrolu pristupa osoba i vozila variraju od objekta do objekta, uloga perimetarske zaštite je svugde slična, a to je: odvraćanje, detek- cija, dokumentovanje i odbijanje - sprečavanje bilo kojeg upada u štićeni prostor ili objekat. U slučaju objekata ili kompleksa koji su locirani van domicilne države situaciju dodatno komplikuje nemogućnost upotrebe sopstvenih vojnih patrola van perimetra. U takvim situacijama, prostor unutar linije ograde može biti upotpunjen zonom bezbednosne prismotre van ograde (sanitarni koridor), gde je perimetar proširen van ograde sa stanovišta ranog upozoravanja. Ovo je veoma važno u situacijama gde bezbednosne snage države domaćina nisu u stanju da obezbede pouzdanu spoljnu bezbednosnu prismotru ili se kompleks od interesa nalazi $\mathrm{u}$ izgrađenim industrijskim, poslovnim, javnim ili rezidencijalnim okruženjima.

$\mathrm{U}$ realizaciji stacionarnih sistema TZOP karakteristično je sledeće:

- uglavnom se koriste komercijalno dostupni senzori za perimetarsku zaštitu;

- procesiranje senzorskih signala (inteligencija) koncentrisano je $\mathrm{u}$ smeru otklanjanja uticaja okoline (šum, klima, urbana sredina i sl.) koji ometaju osnovnu funkciju senzora, dok je osnovni princip rada, a to je detekcija odstupanja od mirnog - normalnog stanja, ostao nepromenjen;

- kombinuju se perimetarska zaštita, TV nadzor štićenog prostora i objekata pomoću video i termovizijskih kamera i pristupna kontrola osoba i vozila, kod koje je sve izrazitija primena biometrijskih metoda kontrole pristupa osoba (identifikacija, verifikacija i autorizacija osoba na osnovu TV slike lica osobe, otiska prsta, geometrije dlana, karakteristika irisa oka i dr.). 


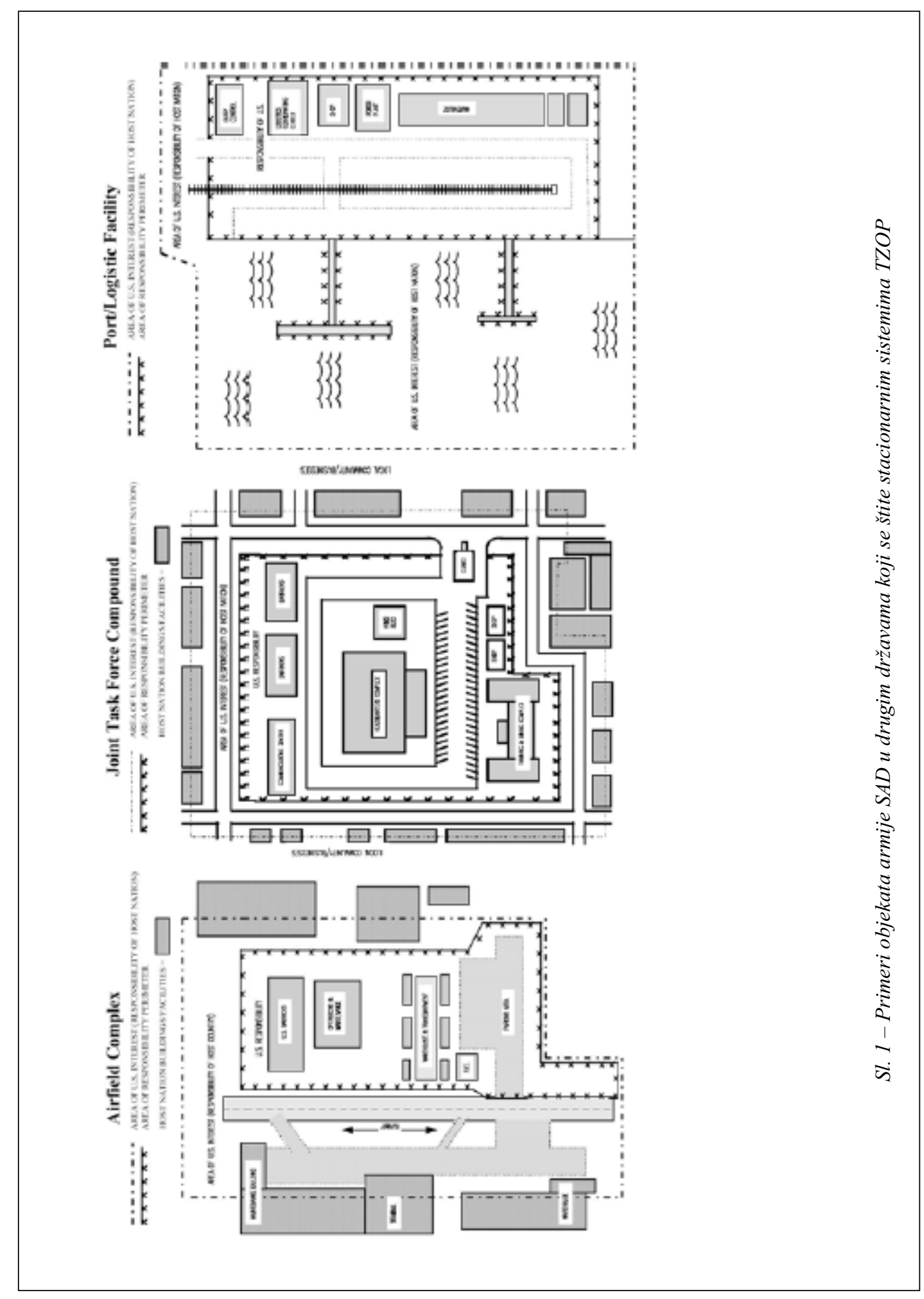


Biometrijski metodi i uređaji mogu se primenjivati i u sklopu sistema za perimetarsku zaštitu objekata u sklopu kojih se primenjuju TV ili termovizijske kamere kao senzori za nadzor prostora van linije ograde oko objekta.

\section{Prenosni sistemi TZOP}

Potreba za prenosnim multisenzorskim sistemima disperziranim u prostoru proistekla je iz mnogih izvornih i specifičnih aplikacija korišćenih od Vijetnamskog rata, rata u Avganistanu, Zalivskog rata pa do savremenih lokalnih ratnih sukoba niskog intenziteta. Ovi sistemi su korišćeni, pored perimetarske zaštite, i za nadzor oblasti u dubini protivničkog borbenog rasporeda (detekcija logističkog saobraćaja i nadzor detektovanih linija snabdevanja). Međutim, navedeni sistemi tipično su bili veliki, skupi i ograničeni u pogledu osetljivosti i mogućnosti pouzdane identifikacije ciljeva.

Savremeni trendovi u ovom domenu vode ka minijaturizaciji i povećanju funkcionalnosti elemenata koji čine jedan prenosni multisenzorski sistem, a to su senzori, sa pratećom akvizicionom i komunikacionom elektronikom, i odgovarajući procesorski prijemni uređaji.

Cilj savremenih istraživačkih i razvojnih aktivnosti u svetu je tehničko rešenje minijaturnih, potrošnih (,,postavi i zaboravi“) i jeftinih senzora namenjenih za izvršenje širokog spektra zadataka. Njihova osnovna namena, na nivou taktičkih jedinica, je postavljanje na određenom opsegu perimetra po dubini borbenog poretka, detekcija zvuka i pokreta, a u novijim rešenjima i generisanje TV slike štićenog perimetra. Savremena sen- zorska rešenja imaju mogućnost obrade signala i prenosa podataka o aktivnostima protivnika, ali i podatke o uslovima zemljišta, klime (temperatura, padavine) i lokalnim aktivnostima okoline (peščane oluje, plima i oseka mora i sl.), prema prijemnom uređaju korisnika posredstvom RF ili satelitskog linka, odnosno bežično (slika 2).

Ove informacije neophodne su svim nivoima komandovanja radi donošenja odluka o vremenu i mestu izvođenja borbenih dejstava, pravcima prohodnosti vozila i primeni posebne opreme. Disperzija senzorskih mreža duboko u oblast borbenog poretka protivnika omogućava pokrivanje delova prostora (džepova) koje nije moguće osmatrati radarom ili termovizijski. Sama disperzija senzorske mreže na željenoj lokaciji vrši se korišćenjem specijalne artiljerijske municije, padobranima ili je jedan od osnovnih zadataka izviđačkih jedinica koje operišu po dubini borbenog poretka protivnika.

Razmatraju se i rešenja multisenzorskih predajnih platformi, zasnovanih na multikontrolerskom pristupu (slika 3), koje bi na jednoj lokaciji prihvatale i vršile obradu signala sa više senzora različitog tipa koji su na njoj raspoređeni, a zatim podatke, putem RF ili satelitskog linka prosleđivale prijemnom uređaju. Time bi se omogućila pouzdana identifikacija uzroka pobude i znatno olakšalo delovanje korisnika ovih podataka.

Prijemnici senzorskih signala na taktičkom nivou ne smatraju se potrošnim uređajima i predviđa se da ih bude nekoliko na nivou jedinice ranga voda. Jedno od mogućih rešenja prijemnog uređaja je ručni personalni računar PAQ firme COMPAQ koji za ovu primenu funk- 

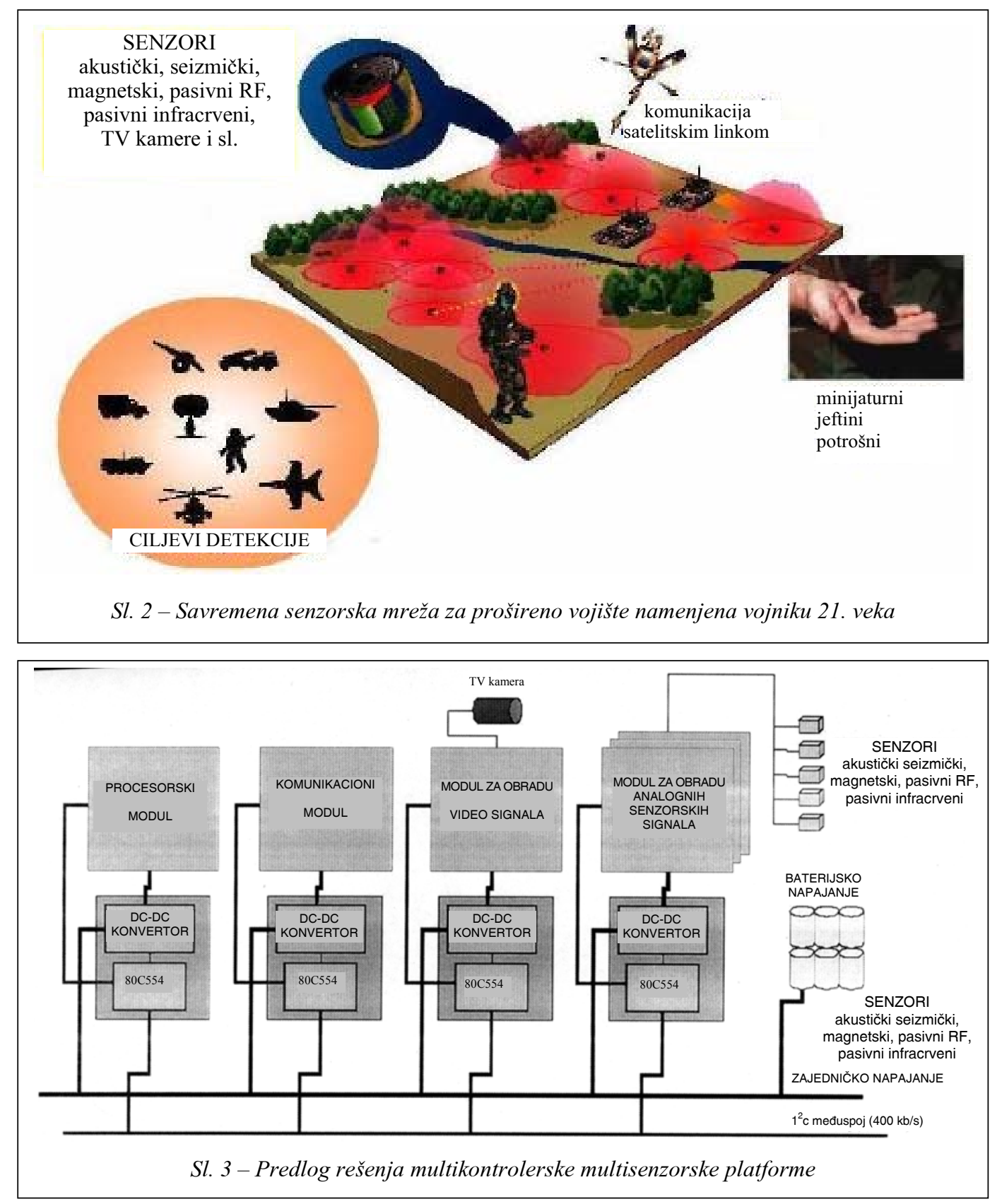

cioniše pod operativnim sistemom LI- kvih senzora potrebno za pouzdano obezNUX (slika 4).

Taktički perimetarski senzori još su u početnim fazama praktične upotrebe, a ispitivanja su pokazala da je desetak ovabeđenje perimetra za individualne taktičke jedinice. Ove male senzorske mreže mogu se koristiti primenom konvencionalnih tehnika multipleksiranja. $\mathrm{U}$ teh- 


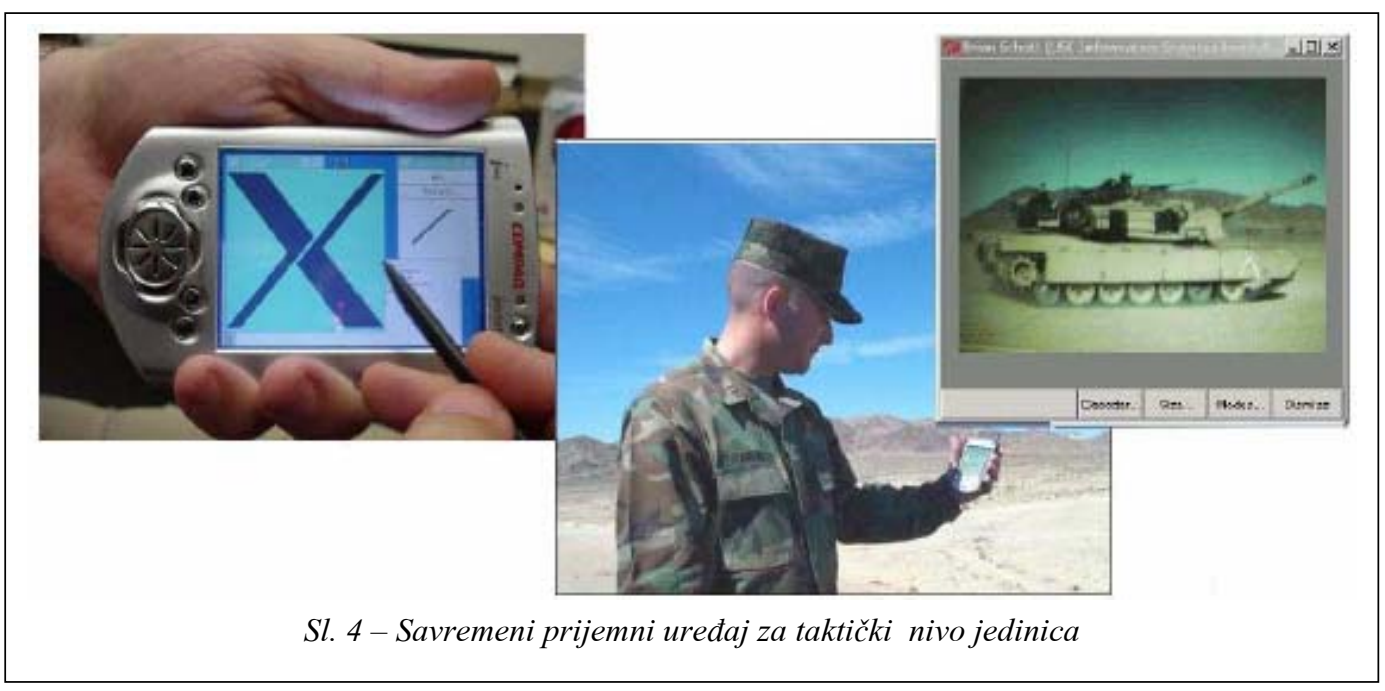

ničkom smislu najizazovnija aplikacija je realizacija velike distribuirane nenadzirane zemaljske senzorske mreže. Kako su funkcije senzora i mrežne aktivnosti postale komplikovanije, zahtevi u pogledu pretprocesiranja podataka suštinski su za izbegavanje informativnog preopterećenja nosilaca odlučivanja. Napredak u domenu nenadziranih senzorskih mreža, odnosno prenosnih sistema TZOP budućnosti, je u primeni elektronskih uređaja male potrošnje energije i tehnologije bežičnog prenosa podataka, što i u razvijenim zemljama, kao što su SAD i države EU, zahteva značajna ulaganja u projektovanje i razvoj ovih sistema.

\section{Iskustva VTI u istraživanju tehničkih rešenja i razvoj uređaja i sistema TZOP}

Istraživanja tehničkih rešenja u oblasti stacionarnih sistema TZOP se u VTI vrše od 1984. godine. U okviru planiranih istraživačkih aktivnosti realizovana su sledeća koncepcijska i tehnička rešenja:
- integrisani stacionarni sistem TZOP, kodni naziv STZOP i podsistem za upravljanje integrisanim stacionarnim sistemom TZOP, kodni naziv MPC, kroz koje su realizovani funkcionalni modeli centralnog računarskog sistema i procesorskih uređaja za integraciju perimetarske zaštite, protivprovalne zaštite (uređaj TES) i kontrole pristupa osoba (uređaj TEK);

- softverski simulator stacionarnih sistema TZOP;

- podsistem za pristupnu kontrolu osoba, kodni naziv POPKONO, koji je kao funkcionalni model eksploataciono ispitivan u VTI, od 1988. do 1993. godine;

- podsistem za TV nadzor, koji je kao funkcionalni model ispitivan tokom 1990. godine i funkcionalni model videokomutacionog uređaja $\mathrm{VK}$;

- modifikacija senzora usvojenih u NVO (mikrotalasni M-2, vibracioni DVD2/25, triboelektrični kablovski TED) radi povezivanja sa uređajem TES.

Većina ovih rešenja primenjena je tokom razvoja sledećih uređaja koji ulaze 
u sastav integrisanog stacionarnog sistema TZOP:

- uređaja MPC, uređaja TES i uređaja TEK (prototipska partija usvojena u NVO 1992. godine);

- zamena računarske konfiguracije iz uređaja MPC personalnim računarom (prototipska partija usvojena 1995. godine).

Započete realizacije razvoja uređaja VK i nulte serije uređaja MPC, TES i TEK prekinute su zbog nedostatka finansijskih sredstava za NIR, i zbog nemogućnosti kooperanta Ei PE iz Niša da zbog sopstvenih kadrovskih i finansijskih problema završi započete aktivnosti. Stečena iskustva i definisana koncepcija integracije stacionarnih sistema TZOP omogućili su timu stručnjaka iz VTI da projektuju i učestvuju u realizaciji više sistema ovog tipa, korišćenjem komercijalno dostupnih senzora, uređaja i softverske podrške, na objektima posebne namene od 1997. godine kao i da započne istraživanja $u$ domenu primene biometrijskih metoda $\mathrm{u}$ realizaciji sistema TZOP (posebno podsistema za pristupnu kontrolu osoba). Ovim treba da se premosti evidentan tehničko-tehnološki zaostatak u domenu projektovanja i razvoja savremenih stacionarnih sistema TZOP.

Istraživanja tehničkih rešenja prenosnih sistema započeta su 1988. godine, a njihov rezultat su funkcionalni model procesora seizmičkih signala (kodni naziv PSS) i više funkcionalnih modela piezoelektričnih senzora sa pratećom analognom elektronikom za predobradu senzorskih signala. $\mathrm{Na}$ osnovu ovih rezultata započet je 1994. godine razvoj prenosnog sistema za identifikaciju kretanja, kodni naziv PRESEK.

\section{Sistem PRESEK}

Sistem PRESEK (slika 5, proširena konfiguracija) namenjen je za tehničku zaštitu objekata i prostora, odnosno komandnih mesta, stacionarnih i pokretnih centara veze, jedinica na logorovanju i zastanku, državne granice, skladišta municije i materijalno-tehničkih sredstava, goriva, vojnih bolnica, aerodroma i dr. pri čemu omogućava: otkrivanje uzročnika pobude (jednog ili više), identifikaciju uzročnika (u smislu distinkcije pešak ili vozilo) i određivanje pozicije pobude $u$ zaštićenom prostoru.

Senzorski podsistem sistema PRESEK u osnovi se sastoji od pasivnih senzora-detektora vibracija-geofona DV-1, primopredajnika PRESEK D i komunikacionih modula (radio-modul, repetitor, priključne kutije PK1-Ž i PK1-R). Analizom geofonskih signala u primopredajniku PRESEK D vrši se detekcija i identifikacija uzročnika pobude.

Radio-senzor PRESEK-RS takođe u osnovi ima ovaj tip senzora samo što se senzorski signali prenose radio-putem, od radio-modula direktno ili preko repetitora, do priključne kutije PK1-R primopredajnika PRESEK D. Primopredajnik PRESEK D povezan je žičnim (preko modema) ili radio-putem (preko svog radio-modula) sa prijemnikom PRESEK $P$ iz sistema PRESEK gde se vrši prikaz signala. Prijemnik je deo sistema PRESEK koji ima zadatak da primljene podatke iz primopredajnika obradi i prikaže na standardnom VGA ili LCD (TFT) monitoru, a po zahtevu podaci se mogu štampati.

Mobilnost i brza rekonfiguracija sistema zasnovani su, pre svega, na 


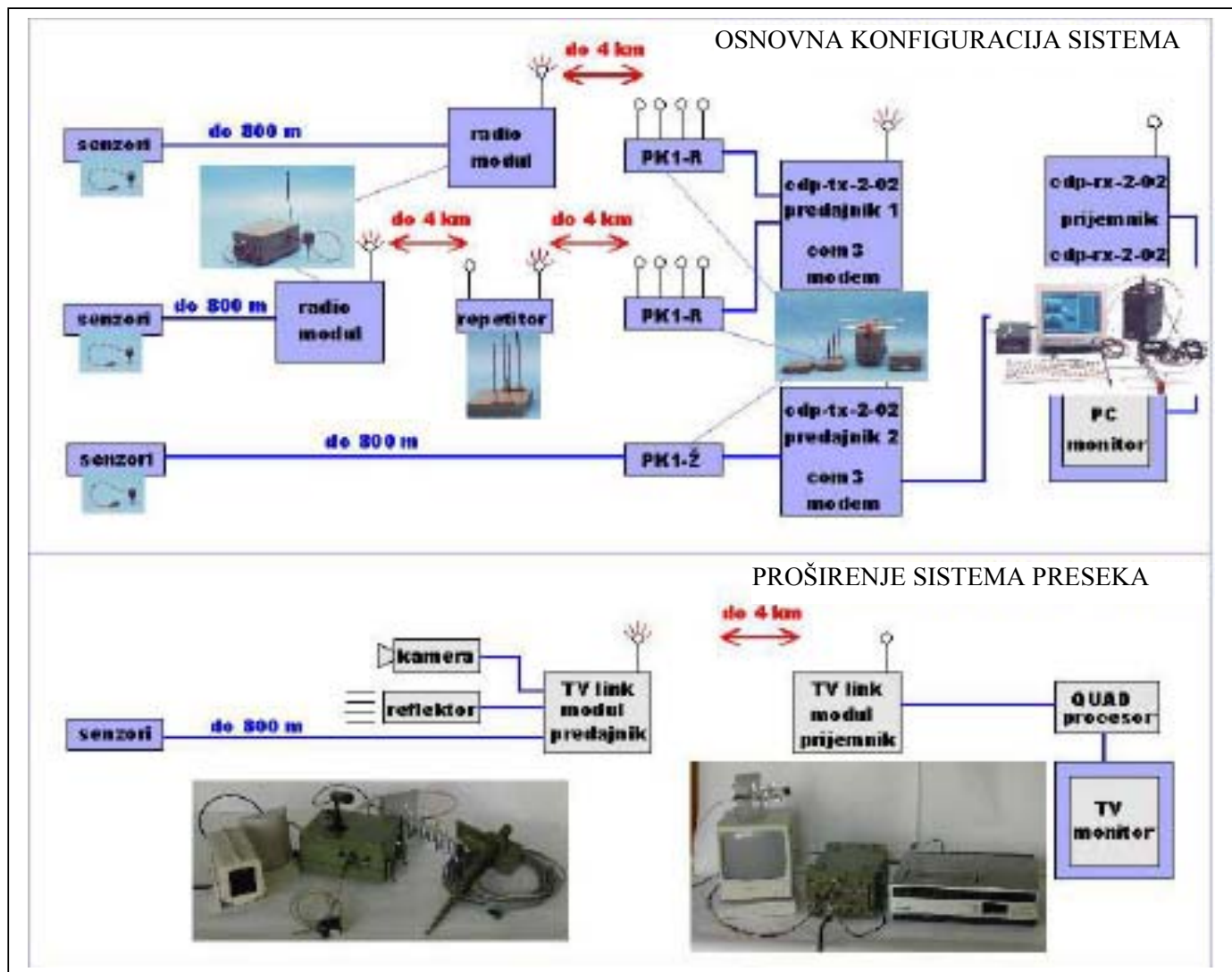

Sl. 5 - Blok-šema realizovane proširene (dodatkom kamere i TV linka) konfiguracije sistema PRESEK

bežičnom prenosu senzorskih signala podataka i TV slike. Na ovaj način moguće je detektovati pobude sa tačkastih lokacija koje su udaljene do 4 $\mathrm{km}$ od primopredajnika PRESEK D, a sa upotrebom repetitora domet se duplira, s tim da postoji optička vidljivost između antena na predajnoj i prijemnoj strani. Video nadzor tačkaste lokacije moguć je na daljini od $4 \mathrm{~km}$ od prijemnog uređaja TV signala koji se postavlja uz prijemnik PRESEK P, $\mathrm{u}$ proširenoj konfiguraciji sistema namenjenoj za trupna ispitivanja. Primenom raspoloživog broja žično povezanih senzora iz osnovnog kompleta sistema PRESEK moguće je zaštititi pe- rimetar dužine $1,2 \mathrm{~km}$ i širine do $50 \mathrm{~m}$, dok se sa proširenim kompletom može ostvariti zaštita perimetra dužine oko 3 km (širinu diktira osetljivost detekcije geofona koja varira u zavisnosti od tipa tla: oko $10 \mathrm{~m}$ za tvrde podloge pa do $100 \mathrm{~m}$ za pesak). Svi navedeni parametri potvrđeni su kroz brojna opitno-eksploataciona ispitivanja. Ovde treba napomenuti da je platforma sa TV linkom istovremeno i prvi funkcionalni model multisenzorske platforme, s obzirom da omogućava povezivanje geofona, pasivnog infracrvenog senzora kretanja, deonice aktivne infracrvene barijere iz kompleta uređaja ICO i TV kamere. 


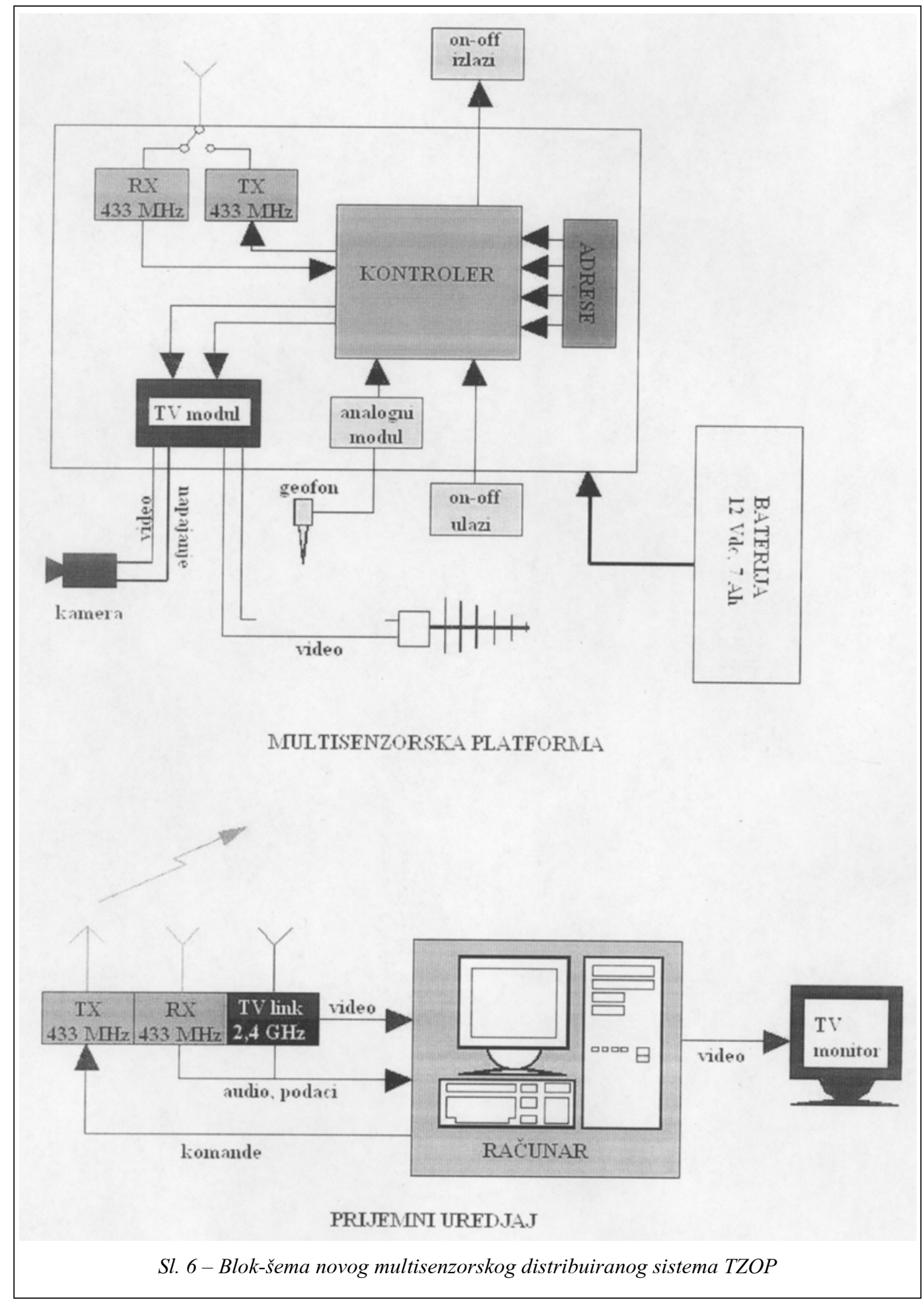




\section{Koncepcija multisenzorskog distribuiranog prenosnog sistema TZOP}

$\mathrm{Na}$ osnovu rezultata dostignutih $\mathrm{u}$ sistemu PRESEK, a u skladu sa trendom realizacije sistema za elektronsko nadziranje prostora, izvršena je modifikacija radio-senzora iz kompleta sistema PRESEK u multisenzorsku akvizicionu radioplatformu sa TV kamerom i TV linkom za prenos slike, koja može da prihvati signale sa više različitih pasivnih ili aktivnih senzora. Ispitivanje ovako modifikovane radio-platforme integrisane u sistem PRESEK potvrdilo je ispravnost koncepta, pa je pokrenut novi razvoj sistema TZOP na bazi multisenzorske akvizicione radio-platforme kao osnovnog uređaja (slika 6).

Osnovni taktičko-tehnički zahtevi koje treba da zadovolji nova akviziciona multisenzorska radio-platforma su:

- što manje dimenzije;

- zadovoljenje klimomehaničkih zahteva za uslove K3;

- minimalna autonomija rada koja je taktički prihvatljiva;

- multikontrolersko upravljanje i obrada senzorskih signala na nivou platforme;

- mogućnost priključenja aktivnih i pasivnih senzora koji rade na različitim fizičkim principima (elektromehanički, optoelektronski, akustički, elektromagnetski, itd.);

- poludupleksna radio-komunikacija sa centralnom stanicom radi upravljanja radom platforme, senzora, prenosa TV slike i priključene periferije;

- prenos TV slike posebnim TV linkom na učestanosti koja je različita od osnovne komunikacione učestanosti radio-platforme.

Ovako definisana multisenzorska akviziciona platforma sa svojim periferijskim okruženjem, predstavlja osnovnu ćeliju sistema koji bi se sastojao od više multisenzorskih akvizicionih platformi i odgovarajućeg centra za nadgledanje $u$ koji se slivaju podaci sa svih akvizicionih platformi kao i TV slike štićenog prostora.

Svaka ćelija, postavljena na terenu, je u režimu čekanja, pri čemu su aktivni samo neophodni podsistemi: komunikacioni podsistem i senzorski podsistem. $U$ trenutku aktiviranja senzorskog podsistema kontrolerski podsistem procenjuje i odlučuje o aktiviranju predajnog dela komunikacionog podsistema i slanju podataka o aktivnosti u zoni reagovanja priključenih senzora. Po dobijanju potvrde iz centra, koja može da bude automatska ili na osnovu odluke operatera sistema, kontroler aktivira TV kameru i TV link za prenos slike štićenog prostora u centar. Osim upravljanja sistemom, u centru se memorišu svi podaci dobijeni od multisenzorskih akvizicionih platformi kao i TV signali štićenog prostora, i omogućava prosleđivanje informacija drugim korisnicima posredstvom žične ili bežične LAN/WAN računarske mreže.

\section{Zaključak}

$\mathrm{Na}$ osnovu analize trendova $\mathrm{u}$ domenu savremenih sistema TZOP, stacionarnih i prenosnih, može se zaključiti da u pogledu koncepcije sistema ne zaostajemo za svetskim rešenjima. Evidentno tehničko-tehnološko zaostajanje delimično je moguće nadoknaditi primenom 
kvalitetnih komercijalnih senzora, komunikacionih uređaja i softverske podrške, koji, uz odgovarajuće dorade u potpunosti mogu da zadovolje postavljene taktičko-tehničke zahteve i za stacionarne i za prenosne sisteme.

U radu su pregledno izloženi istraživački i razvojni rezultati koje je VTI u saradnji sa svojim kooperantima postigao tokom dve decenije rada u domenu sistema TZOP. Naznačeni su i dalji pravci istraživanja i razvoja, koji se odnose na primenu biometrijskih metoda u realizaciji stacionarnih sistema TZOP, posebno $\mathrm{u}$ domenu kontrole pristupa osoba, i u razvoju nove multisenzorske akvizicione platforme za multisenzorski prenosni sistem. Veći deo taktičko-tehničkih zahteva za multisenzorsku akvizicionu platformu, kao osnovni uređaj novog sistema je proveren kroz model koji je integrisan $\mathrm{u}$ postojeći sistem PRESEK. Rezultati su pokazali opravdanost uvođenja prenosa TV slike štićenog prostora kao najkompletnije informacije za odlučivanje, pri čemu se odluka donosi na nivou centra, što pojednostavljuje i pojeftinjuje senzorski podsistem i podsistem za upravljanje na nivou akvizicione platforme. Takođe, jasno je da pouzdan rad sistema počiva na kvalitetnoj komunikaciji koja treba da zadovolji više tehničkih zahteva (više radne frekvencije, što manja snaga zračenja, uska usmerenost zračenja), ali i na doslednom poštovanju zahteva i taktičkih radnji propisanih za postavljanje i rad sa ovakvim sistemom.

Problematika izložena u ovom radu vezana je za tekuće istraživačko-razvojne zadatke u Vojnotehničkom institutu iz oblasti sistema za zaštitu objekata i prostora, i to: razvoj sistema PRESEK (faza završnih ispitivanja), razvoj multisenzorskog sistema za zaštitu objekata i prostora (faza izrade Programa realizacije), i istraživanje tehničkih rešenja za primenu biometrijskih metoda i uređaja u sistemima TZOP (faza izrade Programa realizacije).

Literatura:

[1] Koenig, A. J.; Taylor, L.: Perimeter security sensor technologies handbook, DARPA, NISE East 1997.

[2] Srour, N.: Army acoustics needs, US Army Research Laboratory 1999.

[3] Riley, R., Pads algorithms, USC Information Sciences Institute 2000.

[4] Parker, R.: Distributed sensors group goals, metrics and challenges, USC Information Sciences Institute 2000. 